\title{
KEUNIKAN BATU AKIK GARUT SEBAGAI SALAH SATU DAYA TARIK PARIWISATA DI KABUPATEN GARUT
}

\author{
${ }^{1}$ Desi Qoriah ${ }^{2}$ Cecep Hamzah Pansuri \\ ${ }^{1}$ desiq@uniga.ac.id \\ ${ }^{2}$ cecep@uniga.ac.id \\ ${ }^{12}$ Universitas Garut Jl. Samarang No.52 A Hampor
}

\begin{abstract}
The purpose of this study is to determine the uniqueness that contained in Garutan Gemstone as a tourism attraction. This research focuses on exploring the uniqueness of Garutan Gemstone physically, the shape and color as well as other functions apart from being an accessory such as a therapeutic tool, a body energy transmitter and other things that are believed by the community. This type of research is descriptive qualitative research. The technique of determining the informants in this study was purposive sampling, while the data collection method used semi-structured interviews and documentation. The data validity test used in this study was the triangulation of sources. The data analysis techniques used in this study were reduction, data presentation, and conclusion / verification.
\end{abstract}

Key words : Uniqueness of Gemstone, Characteristic of Garut Gemstone, Garut Gemstone

\begin{abstract}
ABSTRAK
Tujuan dari penelitian ini adalah untuk mengetahui keunikan yang terkandung dalam batu akik Garutan sebagai salah satu daya tarik pariwisata. Penelitian ini terfokus menelusuri keunikan apa saja yang terkandung dalam batu akik baik secara pisik yaitu bentuk dan warna juga fungsi-sungsi lain selain sebagai aksesoris seperti sebagai alat terapi, pemancar energi tubuh dan hal-hal lain yang diyakini masyarakat. Jenis penelitian yang digunakan adalah penelitian kualitatif deskriptif. Teknik penentuan informan dalam penelitian ini adalah purposive sampling, sedangkan metode pengumpulan data menggunakan wawancara semi-terstruktur dan dokumentasi. Uji keabsahan data yang digunakan dalam penelitian ini adalah triangulasi sumber. Teknik analisis data yang digunakan dalam penelitian ini adalah reduksi, penyajian data, dan penarikan kesimpulan / verifikasi.
\end{abstract}

Kata kunci: Keunikan Batu Akik, Ciri khas Batu akik Garut, Batu Akik Garut 


\section{PENDAHULUAN}

Ketertarikan seseorang dalam memiliki sebuah barang salah satunya adalah karena keunikan barang tersebut yang membuat orang merasa ingin memilikinya. Sebuah barang dikatakan unik karena memiliki ciri-ciri tertentu yang berbeda dengan hal lain dan memberikan manfaat dan juga kepuasan bagi pemilik atau calon pemiliknya. Dari keunikan inilah seseorang akan berusaha untuk mendapatkan barang yang bersangkutan baik untuk dimanfaatkan terhadap sesuatu atau hanya sekedar memberi kepuasan dengan hanya memiliki barang tersebut. Seperti halnya batu akik terutama batu Akik Garutan yang keberadaanya sempat hampir mengejar keberadaan batu intan dan berlian dari sisi pamor maupun harga. Secara fisik, batu akik di gunakan manusia sebagai perhiasan atau hal yang memperindah penampilan yang membuat pemakainya merasa memiliki dandanan dan terlihat berbeda. Seperti yang di ungkapkan Keller (1982) dalam Artikel nya yang berjudul "gemstone and its origin" Januari 1982, Helsinki, Finland DOI: 10.1007/978-1-4684-6674-4, menyatakan bahwa "Gemstones have been used principally for personal adornment. And this usage has determined their necessary attributes: they must be beautiful, durable, and rare. A gemstone's beauty enhances the appearance of its wearer. A gemstone must be durable to withstand the rigors of wear and to be passed from generation to generation".

Garut dengan sebutan "Swiss van Java" di identikan keindahannya seperti keindahan yang dimiliki kota Swiss dengan udara yang dingin sejuk serta keindahan alam yang dimilikinya. Keindahan kota Swiss van Java ini terkenal sejak dahulu kala dan di kenal sampai ke luar negeri. Sehingga Garut cukup sering dikunjungi para pesohor negri dan luar negeri seperti kunjungan Charlie Chaplin yang lebih daari satu kali berkunjung ke kota Garut. Seperti di kutip dari Liputan 6 edisi 04 Agustus 2015 pukul 10:32 WIB link https://www.liputan6.com/citizen6/read/2285329/ternyata-charlie-chaplin-pernah-mampir-kegarut-dua-kali, menyatakan "Charlie Chaplin pernah datang mengunjungi Garut 2 kali pada tahun 1927 dan tahun 1935, berangkat dari jakarta charli berhenti distasion Cibatu Garut, setelah Charli turun dari stasiun KA sejauh mata memandang terlihat berbagai gunung yang mengelilingi kota Garut ini setelah itu Charlie menginap di Hotel Grand Ngamplang nah dari situ bisa dilihat kenapa Garut menjadi dikenal kota Swiss terlihat keindahan kota seperti kota swiss menurut Charlie Chaplin dan ketika malam terasa dingin nya Eropa di ngamplang tersebut".

Batu akik sudah menjadi hal yang di teliti banyak pihak baik di dalam negeri atau para peneliti asing. Mereka mempercayai bahwa setiap batuan di planet ini mempunyai energi dan power tertentu, terutama batuan alami yang terbentuk oleh alam selama puluhan tahun bahkan ribuan tahun. Para gem stoner dan crystaler meyakini bahwa semua benda di semesta ini memiliki atau memancarkan vibrasi, begitu juga batu akik yang vibrasi dan energinya bisa dimanfaatkan oleh mahluk hidup lain yaitu oleh manusia hewan dan tumbuhan. Batu akik atau Gemstone dipercaya banyak orang dari berbagai belahan bumi memiliki kekuatan metafisik yang nyata yang mampu mengkoneksikan manusia dengan berbagai hal dalam bentuk metafisik.

Dari kegunanan serta keunikan yang terkandung dalam batu akik ini lah, nilai ekonominya pun menjadi berharga serta memiliki nilai jual yang cukup baik. Bahkan banyak yang memburu batu akik ini sampai harus bejual beli antar negara. Seperti dikutip dari Detiknews edisi 07 Januari 2015, diketahui salah satu jenis batu akik Garut yaitu batu akik ohen yang memiliki nilai cukup mahal yaitu lima belas juta rupiah sebesar $20 \mathrm{~cm}$ dari salah satu pengrajin batu akik di Garut selatan. Nilai ekonomi pada batu akik memberikan peluang bisnis yang sangat baik terutama di era sekarang dimana batu akik tidak hanya di pandang sebagai perhiasan atau dari sisi mistis, tetapi setelah banyak penelitian tentang energi baik yang 
terkandung dalam batu akik ini. Ketertarikan para pemakai dan pecinta batu akik masih cenderung bertahan meski tidak sebooming pada tahun 2013-2016.

Batu akik Garut memiliki beberapa varian atau jenis diantaranya batu akik Edong, Batu akik panca warna, Kalimaya, Bacan, ohen dan lain sebagainya. Dari semua jenis batuan akik tersebut memiliki keunikan tersendiri mulai dari keunikan warna, keunikan serat, keunikan paduan corak alami yang menyerupai bentuk tertentu. Misalnya batu akik yang di dalam nya secara bentukan alam memiliki gambar seperti mata, sehingga dinamai "mata semar" yang juga dipercaya memiliki arti tertentu sebagai bahasa dari semesta. Warna-warna yang timbul dari pancaran batu akik juga sangat dipengaruhi oleh cahaya. Sperti yang di ungkapkan C. Simonet,S. Okundi, P.Massai (January, 2002) on Rockland Kenya in their article titled Colouring Gemstones, state "According to Crystal field theory, colors of gemstone are originating from the excitation of electrons in transition elements and color centers. When a transition metal ion has a partially filled shell, the electrons in the outer d-shell orbit the nucleus unpaired. The surrounding ions of the crystal lattice create a force which is known as $a$ "crystal field" and it forms around such a transition element". Bahkan warna pada batuan akik pun memiliki kode kimia tertentu, dan kode kimia tersebut menggambarkan energi yang terkandung didalamnya.

Alur penelitian keunikan batu akik Garut ini dilihat dari tiga dimensi seperti terlihat pada bagan di bawah ini:

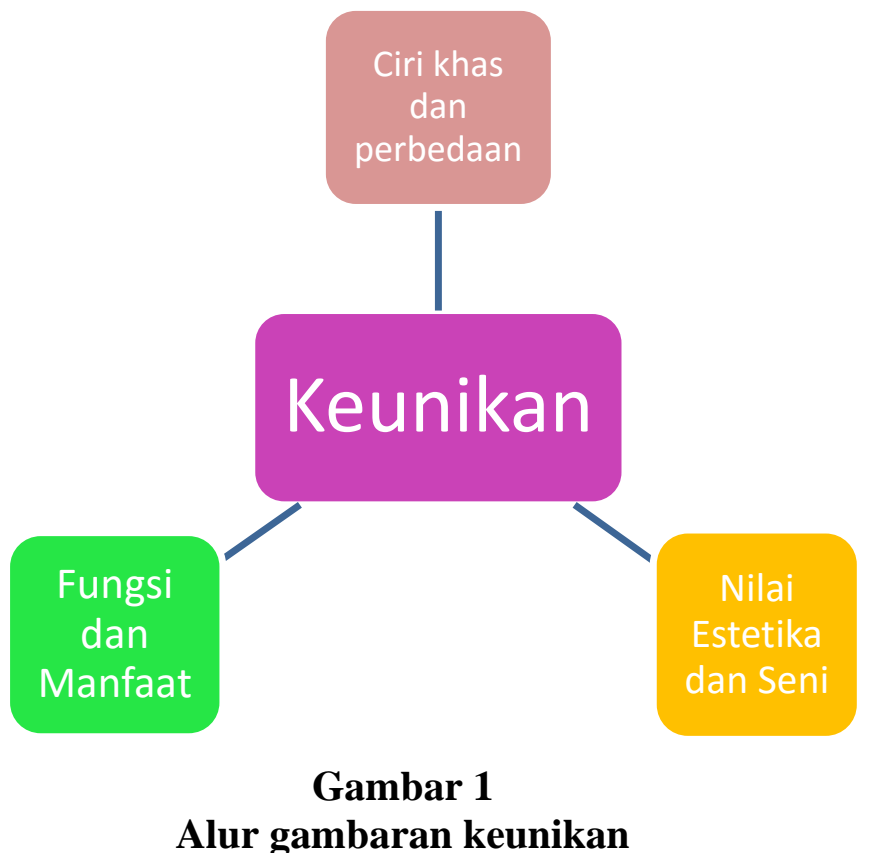

\section{TINJAUAN PUSTAKA}

Mengenai keunikan dalam berbagai hal, sering menarik untuk di teliti karena keunikanya itu. Unik menurut kamus besar bahasa Indonesia (KBBI) artinya tersendiri dalam bentuk atau jenisnya; lain daripada yang lain; tidak ada persamaan dengan yang lain; khusus. Dapat di simpulkan memiliki keunikan adalah memiliki ciri khas tersendiri yang berbeda dengan hal lain dengan barang yang sejenis. Seperti pada journal Jaeni, Muhamad. 2017/10/03, AL-ADDAD yang berjudul Pola unik bahasa Al-Qur'an DOI - 10.28918/religia.v13i1.174 RELIGIA, menyatakan "Keunikan sistem kebahasaan Arab juga terjadi dalam sistem semantiknya. Ada beberapa bagian sistem semantik Arab yang berbeda dengan sistem semantik bahasa yang lain. Tulisan ini akan mencoba membahas wilayah semantik dalam 
bahasa Arab". Beliau mengkaji keunikan pada satu buah bahasa yang memiliki ke khasan tersendiri yang berbeda dari bahasa yang lainya.

Pada penelitian lain tentang "keunikan" ini pada jurnal milik Lars Kadison (2020) yang berjudul "Uniquely Separable Extension" https://doi.org/10.1016/j.exmath.2020.01.003 mengungkapkan bahwa "It is also shown that a uniquely separable extension of semisimple complex algebras with invertible E-index has depth 1. Earlier group-theoretic results are recovered and related to depth 1 . The dual notion, uniquely split extension, only occurs trivially for finite group algebra extensions over complex numbers". Dari penelitian tersebut diketahui bahwa meneliti keunikan dari pola tertentu sangatlah menarik, dan dari keunikan tersebut menjadi daya tarik sendiri bagi kehidupan manusia. selain itu dengan meneliti keunikan sebuah barang atau sesuatu hal maka banyak manfaat yang dapat dimanfaatkan bagi kelangsungan hidup manusia bahkan mahluk lainya.

Dalam meneliti keunikan dari sesuatu hal, seringkali peneliti menemukan hal lain yang bahkan belum sempat diketemukan sama sekali pada penelitian terdahulu dan hal tersebut dapat dimanfaatkan untuk kepentingan atau kebermanfaatan manusia. kebermanfaatan tersebut dapat berupa sumbangsih pada kehidupan sosial, teknologi atau ilmu pengetahuan. Ghosh, Rulsn, Salo dan Uhlmann (2020) dalam penelitianya yang berjudul "Uniqueness and recontruction for the fractional Caldreon problem with singgel measurement" https://doi.org/10.1016/j.jfa.2020.108505 menyebutkan bahwa "We also give a constructive procedure for determining an unknown potential from a single exterior measurement, based on constructive versions of the unique continuation result that involve different regularization schemes". Disitulah nilai keunikan sesuatu salah satunya karena memiliki sesuatu yang belum pernah dieksplorasi atau tidak diketahui oleh banyak orang.

A. Keunikan

Keunikan yang menggemaskan banyak orang yang ada pada batuan batu akik Garut, terkadang dijadikan acuan Gaya hidup. Berbicara mengenai gaya hidup artinya berbicara mengenai trend yang mengikuti perkembangan zaman. Tidak bisa dihindarkan keberadaan perhiasan sebagai pernak-perniknya. Seperti cincin, kalung, gelang, anting dan sejenisnya. Perhiasan bukan hanya emas dan perak, namun ada juga beberapa perhiasan yang terbuat dari batu mulia atau batu permata yang lebih dikenal sebagai batu akik.Akhir-akhir ini, trend memakai perhiasan yang dihiasi batu akik sedang marak di kalangan masyarakat luas dan juga kaum muda terutama di kabupaten Garut meskipun tidak setren tahun-tahun sebelumnya. Dikutip dari jurnal Levy, S. R., West, T. L., Bigler, R. S., Karafantis, D. M., Ramirez, L., \& Velilla, E. (2005). Messages about the uniqueness and similarities of people : Impact on U.S. Black and Latino youth. Journal of Applied Developmental Psychology, 26(6), 714-733. doi:10.1016/j.appdev.2005.08.004 url to share this paper: sci-hub.tw/10.1016/j.appdev.2005.08.004, menyatakan tentang ketertarikan manusia terhadap hal-hal yang unik sebagai berikut "This experiment examined the impact of messages about uniqueness and similarity between groups of people on Black and Latino children's social attitudes. Children (ages 11-14) read two brief science books embedded with a similarities message ("all people are basically the same"), unique message ("each person is unique"), combined similar-unique message ("all people are the same in a way, but each person is also unique"), or no additional message (control)". Keunikan dari sesuatu atau seseorang juga mampu mengkomunikasikan hal-hal tertentu pada orang lain yang melihatnya atau merasakanya.

Energi Gemstone atau batu akik juga dapat bersinergi dengan pemakainya atau bahkan tidak cocok sama sekali, tergantung DNA energi bawaan si pemakai. Misalkan orang yang cepat naik darah, kurang cocok memakai batu mirah delima karena sifat energi mirah delima lebih memacu adrenalin. Merah delima cocok untuk sosok yang pendiam atau pemalas. Yang pemarah lebih cocok memakai black jade yang dapat mengabsorsi 
energi berlebih dan energi buruk. Para peneliti menyatakan warna dan tekstur gemstone mempengaruhi energi yang di salurkanya. Sanne Van der Wal (2017) dalam penelitianya yang berjudul Sustainability issues in the Coloured Gemstone Industry DOI:10.2139/ssrn.1557705 menyatakan "Gemstone colour is divided into three categories which are depended on the chemical composition of the gemstones, and impurity available in the host and false colour. The colour of the gemstone is classified as Idiochromatic, Allochromatic and Pesudochromatic. The Idiochromatic colour means colours formed due to its original chemical composition. The Allochromatic colour means colour formed as a result of presence of impurity available in the gemstone. And the Pesudochromatic colour means colour originated from optical effect"

B. Ciri Khas dan perbedaan

Ciri khas berkaitan dengan beberapa hal dalam yaitu erat kaitanya dengan 1) Jati diri, 2) Identitas, 3) Tanda-tanda, 4) Khas, 5) ciri-ciri, 6) Gambaran. Ciri khas menggambarkan sesuatu yang berbeda dari yang lainya. Dengan memiliki ciri khas sesatu barang atau jasa akan mudah dikenali, apalagi jika ciri khas tersebut langka dan jarang di miliki oleh benda lain biasanya barang atau benda tertentu menjadi buruan atau barang yang paling dicari. Dalam Kamus Besar Bahasa Indonesia sendiri "khas" memiliki arti mengkhususkan; mengsitimewakan atau hal (sifat) khusus yang tidak dimiliki oleh yang lain. Seperti halnya pada batu akik Garut yang memiliki ciri khsa tersendiri yang mungkin berbeda atau tidak dimiliki oleh benda yang lain.

Ciri khas dalam bahasa Inggris berarti "characteristic" yang menggambarkan ciriciri atau identitas sebuah benda. Penelusuran mengenai karakteristik atau ciri khas yang terkandung dalam sebuah hal dipandang penting untuk dilakukan dan hasilnya dapat digunakan dalam berbagai kepentingan. Misalkan untuk membuat sesuatu hal bermanfaat dan berguna, maka sangatlah penting untuk mengetahui karakteristik atau ciri khas hal yang bersangkutan. Sejalan dengan ungkapan Yang dan Huang (2019) dalam penelitianya yang berjudul "Optical Characteristics of silicon recombination random nanostructures for solar cells" yang menyatakan "Therefore, the radiation characteristics of random rough surfaces are important for both academic research and practical applications". Jadi ciri khas dalam sesuatu akan dapat mengembangkan barang tersebut menjadi sesuatu yang berguna dan bermanfaat bagi kepentingan manusia baik secara estetika, secara ekonomi dan sosial.

C. Fungsi dan manfaat

Fugsi dan manfaat adalah dua kata yang memiliki kemiripan tetapi terkadang digunakan dalam konteks yang berbeda dalam sebuah kalimat. Fungsi menunjukan sekelompok aktivitas yang tergolong pada jenis yang sama berdasarkan sifatnya, pelaksanaan ataupun pertimbangan lainnya. Definisi mengenai fungsi tersebut memiliki persepsi yang sama dengan definisi fungsi yang di ungkapkan oleh Sutarto dalam Nining Haslinda Zainal (2008:22), yaitu sebagai berikut, fungsi adalah rincian tugas yang sejenis atau erat hubungannya satu sama lain untuk dapat dilakukan oleh seorang atau sesuatu pegawai tertentu yang masing-masing berdasarkan sekelompok aktivitas/kegunaan sejenis menurut sifat atau pelaksanaannya. Sedangkan pengertian fungsi menurut Kamus Lengkap Bahasa Indonesia merupakan kegunaan suatu hal, daya guna serta pekerjaan yang dilakukan.

Kata manfaat memiliki arti guna atau juga bisa di diartikan berfaedah. Kata pemanfaatan memiliki makna proses, cara atau perbuatan memanfaatkan (Kamus Bahasa Indonesia Kontemporer, 2002 : 928). Pemanfaatan adalah suatu kegiatan, proses, cara atau perbuatan menjadikan suatu yang ada menjadi bermanfaat. Istilah pemanfaatan berasal 
dari kata dasar manfaat yang berarti faedah, yang mendapat imbuhan pe-an yang berarti proses atau perbuatan memanfaatkan (Poerwadarminta , 2002 : 125). Jadi manfaat batu akik adalah ketika batu akik tersebut mampu memberikan kegunaan bagi manusia baik secara pisik ataupun hal-hal lain seperti sebagai asesoris yang bernilai keindahan dan juga sebagai barang yang membangkitkan semangat seseorang.

\section{Nilai Estetika dan Seni}

Estetika adalah sebuah pandangan dimana menggambarkan sesuatu memiliki nilai keindahan yang disepakati oleh umum. Estetika itu merupakan bagian dari seni, seni yang berhubungan dengan keindahan, maka estetika merupakan sebuah pengukuran keindahan akan sebuah seni lagi-lagi yang disepakati oleh umum. Misalkan kupu-kupu selain sebagai binatang penghuni alam, dikatakan estetik karena memiliki warna yang indah dan motifmotif yang unik serta terbang kesana kemari. Maka dari ciri-ciri yang dimiliki kupu-kupu itu dikatakan memiliki nilai estetika. Sehingga tidak jarang kupu-kupu dijadikan simbol atau sering di angkat dalam dunia seni.

Dharsono (2007: 9) mengungkapkan bahwa " fakta estetika itu fakta yang datang dari jiwa, suatu karya seni bagaimanapun nyata tampak, namun bukan pada pengaamatan semula, itu hadir dalam pengamatan dan penikmatan". Hal ini berarti ukuran estetika bukan pada asumsi awal tetapi merupakan proses interpretasi yang panjang dari penngalaman-pengalaman melihat dan merasakan seni. Meskinpun tidak jarang sebuah benda tertentu sudah mampu memikat seseorang dari penglihatan pertama. Dan selanjutnya merupakan sesuatu yang memberikan kenikmatan pada jiwa.

\section{E. Daya Tarik Pariwisata}

Keunikan yang cukup membuat masyarakat luas penasaran akan Batu akik Garut dapat menjadikan daya tarik tersendiri untuk para wisatawan. Karena kedatangan para wisatawan ke sebuah destinasi biasanya akan merasa sangat senang apabila mendapatkan hal-hal baru tentang kepariwisataan, wisatawan adalah orang yang melakukan perjalanan wisata. Selain pemahaman soal wisatawan sebagai orang yang melakukan perjalanan wisata, wisatawan juga dapat dikelompokkan atas berbagai dasar, yaitu atas dasar interaksi (interaction type) dan kognitif-normatif (cognitive-normative models). Pada tipologi dasar interaksi diutamakan pada sifat-sifat interaksi antara wisatawan dengan masyarakat lokal. Sedangkan pada tipologi kognitif-normatif ditekankan pada motivasi yang melatar belakangi suatu perjalanan wisata (Pitana, 2009). Batu akik Garut dengan segala ke khasanya mampu menarik para wisatawan untuk membeli atau paling tidak untuk melihat seperti apa Batu akik yang mampu membangunkan energi tertentu dalam tubuh manusia pemakainya.

Pariwisata sebagai industri merupakan bidang yang kompleks dan keberadaannya peka terhadap perkembangan terutama yang berkaitan dengan motivasi wisatawan yang selalu ingin menikmati pengalaman baru. Kabupaten Garut di era ini sedang menuju kota pariwisata dan memang sudah mendapat kunjungan pariwisata hampir setiap weekend kota ini dipenuhi dengan pendatang. Keberadaan Batu akik salah satu yang cukup dicari oleh para pengunjung terlebih dengan pernah dikenalnya arca berbahan batu akik Garut yang ditawar sampai limabelas Milyar (sumber: Tribunews.com Jumat 7 Agustus 2015). Pariwisata sebagai sebuah peluang industri dapat memberikan peluang ekonomi bagi warga atau penduduk suatu tempat apabila mampu mengetahui keunikan yang dapat di akses di daerahnya. Seperti dikatakan oleh A. Gkoumas (2019) dalam jurnalnya yang berjudul "Evaluating a Standard for Sustainable tourism through the lense of local industry" Volume 5, Issue 11, November 2019, e02707 yang menyatakan "The findings indicate that structural idiosyncrasies of cultural, political and socio-economic context 
influence the perceptions of the local tourism industry regarding tourism sustainability. According, to the results the incomplete accreditation process, the inability of tourism businesses to comply with technical and operational requirements, inadequate local governance and a general feeling of distrust to local authorities and tourism institutions sabotaged the utility and adoption of the standard"

\section{METODE PENELITIAN}

Jenis penelitian yang digunakan dalam penelitian ini adalah penelitian deskriptif kualitatif, untuk menganalisa, memaparkan dan mendeskripsikan lebih dalam tentang keunikan yang terkandung dalam batu akik garutan. Subjek penelitian yang akan digunakan dalam penelitian ini adalah para para pelaku usaha, kolektor dan pemakai batu akik garutan.. Objek penelitian nilai keunikan pada dimensi ciri khas, fungsi dan manfaat, serta nilai estetika.

Dalam penelitian ini, sumber data diperoleh dari data primer dan data sekunder. Data primer adalah data dalam bentuk fakta, verbal atau kata-kata yang diucapkan secara lisan, gerak-gerik atau perilaku yang dilakukan oleh subjek yang dapat dipercaya, yakni subjek penelitan atau informan yang berkenaan dengan variabel yang diteliti atau data yang diperoleh dari responden secara langsung (Arikunto, 2010 : 22). Dalam penelitian ini diperoleh dari hasil observasi yang dilakukan oleh penulis serta dari studi pustaka. Dapat dikatakan data sekunder ini bisa berasal dari dokumen-dokumen grafis seperti tabel, catatan, SMS, foto dan lain-lain (Arikunto, 2010 : 22). Teknik pengumpulan data dalam penelitian ini menggunakan wawancara dan dokumentasi. Dalam penelitian ini, peneliti akan menggunakan teknik wawancara semi terstruktur. Menurut Sugiyono (2013), wawancara semi terstruktur adalah wawancara yang dalam pelaksanaannya lebih bebas atau terbuka bila dibandingkan dengan wawancara terstruktur. Tujuannya agar tidak terpaku pada pedoman wawancara agar permasalahan dapat dibahas secara lebih terbuka. Dokumentasi dalam penelitian ini berupa kumpulan data yang berkaitan dengan batu akik Garutan.

\section{HASIL DAN PEMBAHASAN}

a. Ciri khas Batu Akik Garutan

Batu Akik Garutan dipergunakan masyarakat salah satunya sebagai aksesoris perhiasan. Tetapi selain itu masyarakat juga menggunakan untuk hal lain. Batu akik Garutan memiliki ciri khas tersendiri baik dari penamaan, dari segi warna dan juga dari segi ketenaran.

Berikut beberapa nama batu akik Garut yang dikenal oleh masyarakat pada umumnya:

Tabel 1

Nama dan penjelasan Batu Akik GArut

\begin{tabular}{|c|l|}
\hline Nama Batu akik Garutan & Deskripsi \\
\hline Batu ijo/ hijau Garut & Batu ijo ini memiliki dua jenis batu ijo garut salah \\
& satunya yang memiliki kualitas super terbaik adalah \\
& jenis chrysoprase yang terdapat pada batu ijo garut \\
& "ohen", batu dengan jenis chrysoprase ini sangat \\
& langka sekali. Beerapa kalangan menyebut batu ijo \\
& ini dengan nama batu cisangkal. Jenis ini adalah \\
& primadona yang paling banyak di buru para \\
& kolektor. Bongkahan batu ini sangatlah sulit \\
& ditemukan, bahkan disinyalir sudah habis. Maka \\
& jangan heran jika harga batu ini super mahal. \\
\hline
\end{tabular}




\begin{tabular}{|c|c|}
\hline Batu Tosca Garut & $\begin{array}{l}\text { Batu Toska Garut memang dikenal tidak sepopuler } \\
\text { ijo Garut, namun Garut Tosca tetap memiliki } \\
\text { peminat yang cukup banyak karena warnanya yang } \\
\text { indah rupaawan. Kisaran harganya ada diantara } 3 \\
\text { juta sampai dengan } 20 \text { juta rupiah. Keberadaanya di } \\
\text { pasaran saat ini hampir sama seperti Ijo Garut, batu } \\
\text { ini juga sudah sangat sulit didapatkan. Jarang sekali } \\
\text { para penambang menemukan bongkahan batu tosca } \\
\text { ini. }\end{array}$ \\
\hline $\begin{array}{l}\text { Batu Pancawarna atau } \\
\text { Lukis Garut }\end{array}$ & $\begin{array}{l}\text { Pancawarna Garut banyak diperoleh dari Desa } \\
\text { Caringin kecamatan Caringin. Sejauh ini penghasil } \\
\text { terbesar ada di wilayah Garut Selatan yang } \\
\text { memiliki anugerah alam menjadi sumber penghasil } \\
\text { batu berkualitas. Salah satu nya adalah batu lukis } \\
\text { atau batu pancawarna yang melegenda adalah Garut } \\
\text { Edong. Batu dengan ciri khas } 5 \text { Warna dalam } 1 \text { Batu } \\
\text { ini, sehingga disebut Batu Panca Warna, juga sangat } \\
\text { melegenda dan mahal harganya. Ini karena warna- } \\
\text { warni dibatuan tersebut seolah-olah merupakan } \\
\text { Lukisan Abstrak pada Batu dan ada juga yang } \\
\text { menyebutnya Batu Gambar Edong. Pancawarna } \\
\text { Edong merupakan galian sekitar tahun 1971. Batu } \\
\text { langaka ini dinamakan edong karena di temukan } \\
\text { oleh Abah Edong. Batu ini adalah batu yang paling } \\
\text { melegenda, bahkan dari beberapa sumber berita, } \\
\text { ada yang menyebutkan batu pancawarana edong } \\
\text { banyak diminati dan dipakai oleh para tokoh dunia, } \\
\text { salah satunya adalah Pangeran Charles. }\end{array}$ \\
\hline
\end{tabular}

Batu akik Garutan memiliki kekhasan penamaan biasanya sesuai dengan orang pertama yang menemukan dan bernuansa nama-nama Jawa Barat seperti: Ohen, Edong, Ijo, Cisangkal, Cingcau, Lukis dan lain sebagainya. Yang paling menjadi promadona dan harganya sampai ratusan juta mengalahkan pamor batu mulia lain adalah pancawarna. Dari segi warna ciri khas dari panca warna ini adalah biasanya memiliki kombinasi 5 warna atau lebih.

b. Fungsi dan Manfaat Batu Akik Garutan

Fungsi dan manfaat Batu akik Garutan berdasarkan wawancara dengan para pemakai, kolektorr dan penjual Batu akik Garut adalah sebagai berikut:

1. Sebagai aksesoris. Fungsi sebagai aksesoris adalah menambah keindahan atau kecantikan pemakainya.

2. Penebal Aura. Batu akik tersusun dari kandungan mineral yang setiap batu memiliki medan energi yang berbeda yang berpengaruh pada pemakainya. Batu akik Garut ini dipercaya mampu menebalkan aura seseorang apabila memakainya.

3. Memperkuat energi ketangkasan. Terutama batu akik garut ijo yang dipercayai mampu membangkitkan energi ketangkasan. Dari dulu banyak jawara Garut mengenakan batu ijo ini untuk kekuatan. Di jaman sekarang juga banyak "preman" yang memakai kalung atau cin-cin ijo ini sebagai alasan untuk kekuatan. 
4. Pemancar energi keayuan. Karakter energi frekwensi suatu batu akik tergantung pada jenis dan elemen pengikatnya sehingga struktur atomnya pun berbeda dan otomatis frekwensinya berbeda (tutur dari praktisi peneliti batuan dan Kristal Ken Pradipta). Batu akik pancawarna dipercaya meningkatkan aura kecantikan.

5. Sebagai komoditi ekonomi. Harga batu jenis Ohen dari Garut pernah mencapai Rp 800 juta di tahun 2015. Pada masa jayanya sempat menguasai pangsa pasar. Sekali pengiriman bisa mencapai 300 sampai 500 batu akik pada masa jayanya.

6. Fungsi Cendra mata. Pada gelaran Asian Games 2018 lalu pernah menjadi cinderamata bergengsi bahkan hingga konferensi tingkat tinggi Asia-Afrika.

\section{c. Nilai Estetika Batu Akik Garutan}

Nilai estetika Batu akik Garutan terletak pada beberapa hal diantaranya pada warna, bentuk dan penamaan. Warna batu akik khas Garut yang cukup diburu dan dianggap estetik yaitu batu ijo, batu toska dan yang paling primadona adalah pancawarna yang memiliki gabungan dari beberapa warna. Batu pancawarna ini bak sebuah lukisan alam yang memakau mata yang memandangnya. Batu pancawarna ini juga berkaitan dengan sejarah Garut ratusan atau bahkan ribuan tahun lalu, ini menandakan bahwa dahulu tanah ini mengandung sesuatu yang terkubur yang tidak dimiliki daerah lain.

Karena batu akik ini merupakan mineral yang terkubur selama ratusan bahkan ribuan tahu lalu yang mengeras dan memiliki tingkat kekerasan tertentu. Batu akik sama halnya dengan batu intan dan batu permata, ditilai dari seberapa keras dan tidak tembus cahaya, semakin keras batu tersebut maka semakin bernilai dan semakin dianggap berkualitas. Tingkat kekerasan batu akik Garutan berkisar pada angka 4 sampai mencapai 7 mohs hampir setara batu mulia intan.

Demikian hasil dan pembahasan mengenai Batu Akik Garutan yang cukup terkenal dan menguasai pasar pada masa kejayaannya. Tetapi meski pamor batu akik sedang menurun. Keberadaanya tetap eksis dan tetap memiliki peminat karena salah satunya memiliki keunikan.

\section{KESIMPULAN DAN SARAN}

Seperti yang telah diungkapkan diatas ternyata batu akik Garutan memiliki keunikan tertentu baik secara bentuk, warna dan fungsi. Diantaranya sebagai berikut:

1. Sebagai aksesoris. Fungsi sebagai aksesoris adalah menambah keindahan atau kecantikan pemakainya.

2. Penebal Aura. Batu akik tersusun dari kandungan mineral yang setiap batu memiliki medan energi yang berbeda yang berpengaruh pada pemakainya. Batu akik Garut ini dipercaya mampu menebalkan aura seseorang apabila memakainya.

3. Memperkuat energi ketangkasan. Terutama batu akik garut ijo yang dipercayai mampu membangkitkan energi ketangkasan. Dari dulu banyak jawara Garut mengenakan batu ijo ini untuk kekuatan. Di jaman sekarang juga banyak "preman" yang memakai kalung atau cin-cin ijo ini sebagai alasan untuk kekuatan.

4. Pemancar energi keayuan. Karakter energi frekwensi suatu batu akik tergantung pada jenis dan elemen pengikatnya sehingga struktur atomnya pun berbeda dan otomatis frekwensinya berbeda (tutur dari praktisi peneliti batuan dan Kristal Ken Pradipta). Batu akik pancawarna dipercaya meningkatkan aura kecantikan.

5. Sebagai komoditi ekonomi. Harga batu jenis Ohen dari Garut pernah mencapai Rp 800 juta di tahun 2015. Pada masa jayanya sempat menguasai pangsa pasar. Sekali pengiriman bisa mencapai 300 sampai 500 batu akik pada masa jayanya. 
6. Fungsi Cendra mata. Pada gelaran Asian Games 2018 lalu pernah menjadi cinderamata bergengsi bahkan hingga konferensi tingkat tinggi Asia-Afrika.

Sedangkan saran dari penulis semoga dapat diteliti lebih lanjut mengenai keunikan batu akik garutan yang mungkin belum tersentuh. Terutama secara ilmiah mengenai kode mineral sehingga mampu diketahui secara logis kebermanfaatanya untukk keperluan manusia baik sisi kesehatan, sisi ekonomi dan fungsi-fungsi lain dalam kehidupan. Karena penulis meyakini semua yang disediakan alam adalah sesuatu yang baik yang dapat digunakan bagi kelangsungan hidup.

\section{DAFTAR PUSTAKA}

[1] Keller, P. C. (1990). Gemstones and Their Origins. doi:10.1007/978-1-4684-6674-4 url to share this paper: sci-hub.tw/10.1007/978-1-4684-6674-4

[2] Liputan6.com edisi 04 Agustus (2015) pukul 10:32 WIB link https://www.liputan6.com/citizen6/read/2285329/ ternyata-charlie-chaplin-pernahmampir-ke-garut-dua-kali

[3] Detiknews edisi 07 Januari (2015). https://news.detik.com/berita/d-2879684/legendaakik-garut-ijo-ohen-yang-langka-dan-lebih-mahal-dari-batu-bacan

[4] C. Simonet,S. Okundi, P.Massai ( 2002) on Rockland Kenya. General setting of coloured gemstone deposits in the Mozambique Belt of Kenya Preliminary considerations.

[5] D.-W., Brik, M. G., Srivastava, A. M., Ma, C.-G., \& Piasecki, M. (2020). Influence of low-symmetry component of crystal field on gemstones colors: Cr3+ in ruby and emerald. Journal of Luminescence, 117061. doi:10.1016/j.jlumin.2020.117061 url to share this paper: sci-hub.tw/10.1016/j.jlumin.2020.117061

[6] Jaeni, Muhamad. (2017). AL-ADDAD .Pola unik bahasa Al-Qur'an DOI 10.28918/religia.v13i1.174 RELIGIA

[7] Lars Kadison .(2020). "Uniquely Separable Extension" https://doi.org/10.1016/j.exmath.2020.01.003

[8] Ghosh,T. Rüland, Salo, M., \& Uhlmann, G. (2020). Uniqueness and reconstruction for the fractional Calderón problem with a single measurement. Journal of Functional Analysis, 108505. doi:10.1016/j.jfa.2020.108505

[9] Levy, S. R., West, T. L., Bigler, R. S., Karafantis, D. M., Ramirez, L., \& Velilla, E. (2005). Messages about the uniqueness and similarities of people : Impact on U.S. Black and Latino youth. Journal of Applied Developmental Psychology, 26(6), 714733. doi:10.1016/j.appdev.2005.08.004

[10] Sanne Van der Wal (2017). Sustainability issues in the Coloured Gemstone Industry DOI:10.2139/ssrn.1557705

[11] Yang, L., \& Huang, Z. (2019). Optical characteristics of silicon recombination random nanostructures for solar cells. Energy Procedia, 158, 998-1003. doi:10.1016/j.egypro.2019.01.243

[12]Nining H.Z. (2008). Analisis Kesesuaian Tugas Pokok dan Fungsi dengan. Kompetensi Pegawai pada Sekretariat . Yogyakarta. Medpress.

[13] Poerwadarminta, W.J.S. (2002). Kamus Umum Bahasa Indonesia. Balai Pustaka. Jakarta. Praja, P. 2002. Dasar dan Prinsip Pengawasan Bank. Gramedia Pustaka

[14]Dharsono. (2007). Estetika. Bandung: Rakayasa Sains. Hasibuan, Jamaluddin S. Art Et Culture/SeniBudaya BATAK. Jakarta: Citra. Indonesia.

[15]Pitana, I Gde, · Diarta, I Ketut Surya. EDISI, ed. 1. Penerbitan, Yogyakarta : Andi, (2009). Deskripsi Fisik, viii, 271 hlm ;23 cm. ISBN, 9789792909289. 
[16]A. Gkoumas. (2019). "Evaluating a Standard for Sustainable tourism through the lense of local industry" Volume 5, Issue 11, November 2019, e02707

[17] Arikunto. (2010). Prosedur Penelitian: Suatu Pendekatan Praktek. Jakarta: Rineka Cipta.

[18] Sugiyono. 2013. Metode Penelitian Pendidikan Pendekatan Kuantitatif,. Kualitatif, dan R\&D. Bandung: Alfabeta 